\title{
Making a Difference - Global Health Technology Success Stories: Overview of over 400 submissions from 125 Countries
}

\section{By T Judd' and Y David²}

${ }^{1}$ IFMBE CED Chairman, Marietta, GA 30068, USA

${ }^{2}$ Biomedical Engineering Consultants, LLC, Houston, TX 77004, USA

\begin{abstract}
Health Technology (HT) is vital to global health care. The dependence of health, rehabilitation, and wellness programs on technology for the delivery of services has never been greater. It is essential therefore, that HT be optimally managed. Clinical and biomedical engineers have been recognized by World Health Organization (WHO) as essential to providing this critical management.

At the 1st International Clinical Engineering and HT Management Congress and Summit held in China in 2015, a resolution was adopted by the global Clinical Engineering (CE) country participants to identify and promote CE unique qualifications, and to record the CE contributions to the improvement of world health status. Review of published literature and submissions of case studies resulted in the first group of CE success stories. The review captured 150 stories from 90 countries - spanning over a period from the prior 10 years and the results were presented to health leaders at the WHO World Health Assembly in 2016. Last year, in 2017, additional 250 case studies from a total of 125 countries were added from the 2016-2017 period. This paper describes the evidence identified during the review, their sources and the 6 major categories they represent.
\end{abstract}

Keywords - Healthcare, Clinical Engineering, Technology Management, Safety, Efficacy, Outcomes, Innovation, Success Stories

\section{INTRODUCTION}

Health Technology (HT) is vital to health and the dependence of health, rehabilitation and wellness programs on HT for the delivery of their services has never been greater. Therefore, it essential that competent and trained professionals manage in an optimal and safe way for better response to the burden of diseases and resources. Trained clinical engineers are academically prepared and

IFMBE-CED is the International Federation for Medical and Biological Engineering (IFMBE)-Clinical Engineering Division (CED), currently representing clinical engineers (hospital-based biomedical engineers) in these roles in 165 countries. See more information about CED at cedglobal.org/organization-and-teams/ appropriately responsible for HT life-cycle management, fulfilling a critical role as members of the healthcare team focusing on availability and reliability of safe and effective technologies and outcomes.

Over the past 50 years growing concerns among Clinical Engineering (CE) professionals about lack of knowledge of government agencies and key stakeholders, coupled with the mute recognition for their vast contributions to the safe and effective creation and deployment of HT, led to programs that address these concerns. Knowledge about 
and recognition for the professionals of CE community who provide critical services will help recruit students and future practitioners into this needed field. Is CE practice important for health, rehabilitation, and wellness programs and are their contributions recognized? This paper shares the methodology and the findings identified following a three-year examination of published evidence.

Following the international congress on CE and HT management in Hangzhou, China in 2015, a Global CE Summit took place to determine whether regional issues are shared across the world and present common international challenges requiring global strategy for optimal addressing of the critical issues. After order ranking of the issues that identified at the end of the Global CE Summit, the attending members voted that there were 2 major concerns: (1) a lack of understanding of and recognition for the CE contribution to improvements in healthcare delivery. (2) a lack of sufficient education and training for both those who would like to enter the field and for ongoing professional development. An action plan was devised to address these and other issues raised at the summit. At the second global CE summit in Sao Paulo, Brazil, in 2017, these challenges were reviewed and confirmed with attendees adopting resolutions seeking to continue to address these concerns. The action plans from the summit focused first on data collection identifying if CE contributions qualify as improvement to world health and wellness and can they be substantiated through evidence-based records. Addressing the second issue, an international survey of Body of Practice and Body of Knowledge was initiated and has been now completed.

\section{METHODS}

\section{Rationale}

A task force consisting of senior certified clinical engineers from IFMBE/CED issued a global call for submissions of evidence-supported case studies of CE contributions to the improvement of delivery of healthcare services or of patient outcomes. In addition, literature survey was performed in 2016, and of both sources, the literature and the submitted studies, an aggregate volume of 150 responses from 90 countries was examined and qualified as evidence-based contributions, (see http://global. icehtmc.com/publication/healthteachnology).
Results were rated and tabulated into categories (Innovation, Improved Access, Health Systems, HT Management, Safety \& Quality, and e-Technology) and incorporated into document http://global.icehtmc.com/publication/ globalsuccess that was submitted to WHO's World Health Assembly in May 2016.

We expanded our review in 2017, as submissions and publications continued to be collected, to include conference-accepted data that was presented and published at IFMBE sponsored events. Our examination methodology identified 250 additional stories from 35 more countries - now raising the total volume over 2 years to 400 publications from 125 countries. These CE success stories point to improved outcomes with benefit from HT, and present overall demonstration of complex integrated systems that must be effectively managed for their optimal and safe clinical and business impact to be realized. Clinical outcomes included change in human life quality, care management decisions support, improving $365 \times 24 \times 7$ readiness, and improving operational efficiency.

\section{Definitions}

For the present study, we classified the collected database into 6 categories with definitions:

\section{- Innovation}

Through provision of new HT solutions, adaptation of existing, or a combination to address several issues.

\section{- Improved Access}

Ease in reaching HT-related health services or facilities in terms of location, time, and ease of approach.

\section{- Health Systems}

Positive impact from more efficient and effective deployment of HT at national or policy level.

\section{- Safety \& Quality}

HT's positive impact on health services safety or quality outcomes, or through HT human resource development.

- Healthcare Technology Management (HTM) Establishing or improving HTM methodology resulting in improved population health or wellness.

- e-Technology

Improvements achieved due to deployment of Internetbased HT tools. 


\section{Measures}

During the first Global Clinical Engineering Summit in 2015 the question was raised whether evidence of successful HT innovation, management, accessibility, e-technology applications, safety, and quality outcomes can be identified. To accomplish this, a successful project (or submission) was defined as satisfying 2 objective measures developed by the sponsors. These measures included timeliness, cost saving, deployment or adoption by care providers, impact on services, and overall projection for success. Each success metric was evaluated using 3-point scale against a statement representing the success construct (1= strongly disagree; $3=$ strongly agree).

- Timeliness refers to whether the project/submission was implemented in timely manner. This was measure by the statement "The submission will impact outcomes on present time."

- The cost measure was evaluated by whether the submission's overall costs were within budget constraints and reasonable for the conditions in the region. This was assessed by the statement, "The submission cost objectives can be met in the region."

- The next 2 metrics were combined into the statements "The submission will be deployed by its intended users" and "The submission will have a positive impact on those who will adopt it."

- Finally, overall submission success expectations were assessed with the statement "All things considered, the submission will be a success."

Innovation is the beginning of the technology life cycle where new ideas offer solutions to current problems faced by healthcare providers or their patients. Clinical engineers are well positioned to understand the current problems and guide different or new approaches to resolve them. Innovation, in our category, means to demonstrate the team approach to solving problems all the way from the concept and building of a prototype, to continuing with clinical trials, and a demonstration of compliance with standards, regulations, and intended outcomes. Improved Access to services follows the innovation stage the same as the Safety and Quality category, e-Technology category, and HTM. Products and applications that are considered in successful deployment were rated high and included in the total count for the evidence-based category.

\section{RESULTS}

Summaries of the 6 categories of submissions database are described below. They come from the CED's 2016 Health Technologies Resources ${ }^{1}$ document provided to the World Health Assembly, WHO's May 2017, $3^{\text {rd }}$ Global Forum on Medical Devices ${ }^{2}$; (3), the CED's September 2017 Sao Paulo II ICEHTMC ${ }^{3}$ (S), and others ${ }^{4}$ from 2016-2017 IFMBE published sources (0):

A new resource summary document of the findings - with links below - demonstrates that a benefit was registered in the 6 categories from every region around the world. Overall this review identified evidence from 400 case studies received from 125 countries where management of medical devices (main component of health technologies) made a positive difference over the past 12 years.

The 2007 WHO WHA Resolution 60.29 urges Member States to create national HT management plans in collaboration with biomedical engineers. WHO further clarified the definition of these personnel in 2017-2018 as part of a global survey ${ }^{5}$ (http://www.who.int/medical_devices / support/en/) in coordination with IFMBE CED.

"Trained and qualified biomedical engineering professionals are required to design, evaluate, regulate, maintain and manage medical devices, and train on their safe use in health systems around the world. ${ }^{5}$ "These occupations have various names in different countries like clinical engineers, medical engineers, ... and related professionals and technicians. [WHO and IFMBE CED surveys have identified over 800,000 of these global professionals in 2018.]

The case studies - grouped in 6 categories - aim to formulate national strategies and plans to improve use of health technologies and better manage costs. In several countries, this has best been achieved by developing a HT unit at the Ministry of Health level with CE leadership. The studies provide clear evidence that HT is beneficial; at times, presenting complex systems that must be effectively guided and managed for optimal impact to be realized. 
- Innovation

- Access

- Management

- Health Systems

- e-Technology

- Quality \& Safety

The case studies are actually Health Technology Success Stories demonstrating, in a limited resource environment, that it is desirable to include professional HT expertise, such as clinical engineers, in national decision-making in order to maximize health systems' services. Case studies from the links on the following pages demonstrate these benefits:

- Access: The Ministry of Health HT Unit-led project in Albania that doubled access to critical diagnostic services, such as computed tomography scanners, magnetic resonance and angiography imaging, while reducing equipment downtime to zero, and significantly reducing cost.

- Health Systems: Improved coordination between multiple stakeholders in the National Laboratory and its satellites in Colombia, led by the Ministry of Health and clinical engineers who partner with experts from academia and industry.

- Quality \& Safety: A clinical engineer-led 122-hospital program in the Shanghai region that cooperates with officials, industry, and academic entities, resulting in improved device user satisfaction, tracking of emerging technologies, and closer partnerships with industry.

\section{CONCLUSIONS}

HT is vital to health and the dependence of health, rehabilitation, and wellness programs that rely on HT for the delivery of their services has never been greater. Beyond the ongoing healthcare burdens of population growth, political and economic instability, disease management, disasters, the refugee crisis, accidents, and terror attacks, world healthcare technological systems are facing enormous challenges to be innovative and optimally managed. The transition into health programs for the 21st century requires the employment of trained competent CE professionals. Disease prevention, treatment, and rehabilitation is more efficient and effective when health services are provided with appropriate tools. Along with World Health Organization (WHO), the International Federation for Medical and Biological Engineering (IFMBE) Clinical Engineering Division (CED) recognizes and emphasizes how important the use of appropriate, integrated, and safe health technologies (HT) is to successful outcomes for every healthcare delivery systems. In the May 2016 HT resource document that was prepared for the World Health Assembly (WHA), a recommendation was made: Health technologies must be managed to ensure full clinical benefit and expected financial return on investment.

It is critical, therefore, that with limited resources, HT must be professionally managed and its deployment over its life cycle be appropriately guided. This paper describes the extensive study of published data on the vast contributions by CE that positively impact patient outcomes. This study shows that every region of the world including low-resource regions face a challenge of improving health services while facing varied levels of infrastructure and human resources capacity challenges. CEs play vital roles in all stages of healthcare technology life-cycle management. From creation to planning, and from commissioning to utilization and integration; technology-based systems must and can be managed for optimal performance. In each of the technology life-cycle stages the requirement for trained and competent CE input makes critical difference as shown in the analyzed evidence reviewed here. It is our hope that government agencies and other interested parties will have better understanding of CEs role and thus will support their inclusion in the healthcare team of professionals.

\section{RECOMMENDATION}

To encourage the availability, recognition, and increased participation of clinical engineers as part of the health workforce in your national healthcare delivery programs. ${ }^{2}$

\section{REFERENCES}

1. IFMBE Clinical Engineering Division (CED). [Internet] Health Technologies Resource. Available at: http://cedglobal.org/ global-ce-success-stories/ 
2. World Health Organization. [Internet] Third Global Forum on Medical Devices, May 2017. Available at: http://www.who.int/ medical_devices/global_forum/3rd_gfmd/en/

3. IFMBE CED. [Internet] 2nd International Clinical Engineering and Health Technology Management Congress (II ICEHTMC) Proceedings, September 2017. Available at: http://cedglobal. org/icehtmc2017-proceedings/

4. IFMBE. [Internet]. Other related CE papers. Available at: CEDGlobal.org.

5. World Health Organization. [Internet]. Medical devices: Biomedical engineering resources. Available at: http://www.who. int/medical_devices/support/en/

\section{ADDITIONAL LINKS AND RESOURCES}

- WHO HQ: http://www.who.int/medical_devices/en/

- WHO EMRO: http://www.emro.who.int

- WHO AMRO: http://www.who.int/about/regions/amro/en/
- WHO Digital Health: http://www.who.int/medical_devices/ global_forum/Thedigitalhealthaltas.pdf

- WHO Assistive Devices-GATE: https://mednet-communities. net/gate/

-WHO Emergency: www.who.int/medical_devices/global_forum/ Essentialresourcesemergencycare.pdf

- WHO NCD Kit Refugees: http://www.who.int/medical_devices/ global_forum/NCDkitrefugees.pdf

- IFMBE, CED, HTA: http://ifmbe.org/, http://cedglobal.org/ http://htad.ifmbe.org/

- PATH: https://www.path.org/ (Belgium, China, DRC, Ethiopia, Ghana, India, Kenya, Malawi, Mozambique, Myanmar, Peru, Senegal, RSA, Switzerland, Tanzania, Uganda, Ukraine, Vietnam, Zambia)

- AWHP: www.ahwp.info; Asian Harmonization Working Party - 30 countries, 3/17 Regulatory Authorities

- HTAi: https://www.htai.org/ 


\section{RESOURCES REVIEWED}

\begin{tabular}{|c|c|}
\hline Focus Area & Title, authors, with active links \\
\hline $\begin{array}{l}\text { Afghanistan, Iraq, Libya, } \\
\text { Occupied Palestinian } \\
\text { Territory, Somalia, Su- } \\
\text { dan, Syria, and Yemen }\end{array}$ & Medical Devices for Emergency Kits (NCD Kit), Laura Alejandra Velez, Slim Slama \\
\hline Australia & $\begin{array}{l}\text { Phototherapy to Reduce Exchange Transfusions, Luciano Moccia, Gaston Arnolda, Daniele } \\
\text { Trevisanuto }\end{array}$ \\
\hline Australia & $\begin{array}{l}\text { FREO2 oxygen solutions: the Low-Pressure Oxygen Storage system and FREO2 Siphon, } \\
\text { Roger Rassool, Jim Black }\end{array}$ \\
\hline Australia & $\begin{array}{l}\text { BME development of non-electric portable blood/fluid warmer for roadside trauma, } \\
\text { Anne-Louise Smith, Mark McEwen }\end{array}$ \\
\hline Bangladesh & Health Technology enhancing rural Primary Care and eHealth, Ahmed Raihan Abir \\
\hline Brazil & $\begin{array}{l}\text { Dynamical Orthostatic Chair Development of a new method of lifting and locomotion } \\
\text { for physically disabled people, Walef Robert Ivo Carvalho }\end{array}$ \\
\hline Brazil & $\begin{array}{l}\text { A multiband reflectance photometric device for reveal gestational age at birth, Rodney } \\
\text { Guimaraes, Zilma Reis }\end{array}$ \\
\hline Brazil & $\begin{array}{l}\text { Prematurity detection by light, Zilma Reis, Rodney Nascimento Guimarães, Gabriela Luíza } \\
\text { Nogueira Vitral, Maria Albertina Santiago Rego, Ingrid Michelle Fonseca } \\
\end{array}$ \\
\hline Brazil & $\begin{array}{l}\text { Actions travelling ECG for Telemedicine - a partnership of academic and public service, } \\
\text { Kleber Teixeira de Souza et al }\end{array}$ \\
\hline Brazil & Flow Analyzer for Blood Pump, L.R. Rodrigo, A.M. Marcelo and S. Anderson \\
\hline Brazil & $\begin{array}{l}\text { Principal Component Analysis usage in Biomedical Engineering to aid at diagnosing pa- } \\
\text { thologies, E.F. Esmanhoto }\end{array}$ \\
\hline Brazil & $\begin{array}{l}\text { Digital Storage and System Management for Video surgery Records in a Network Plat- } \\
\text { form, Benedito Fernandes De Lima et al }\end{array}$ \\
\hline Brazil & $\begin{array}{l}\text { Early stage strategic effectiveness evaluation of high flow nasal therapy (OPTIFLOW®) } \\
\text { in the treatment of Acute Pediatric Respiratory Failure, Graziela de Araujo Costa et al }\end{array}$ \\
\hline Brazil & $\begin{array}{l}\text { Location of electromedical equipment in closed environment using wi-fi technology, } \\
\text { William Knob de Souza }\end{array}$ \\
\hline Brazil & Remote Equipment Monitoring System, A. Ricardo Maranho \\
\hline Brazil & $\begin{array}{l}\text { Model fitting and simulation of the respiratory control system under incremental exer- } \\
\text { cise and altitude in healthy subjects, C. A. Sarmiento, A. M. Hernández, L. Y. Serna }\end{array}$ \\
\hline Canada & $\begin{array}{l}\text { Provincial Respiratory Outreach Program in the Province of British Columbia (BC), An- } \\
\text { thony Chan, Esther Khor }\end{array}$ \\
\hline Chile & $\begin{array}{l}\text { Clinical Simulations using actors as a patients as part of a strategic plan to reduce risks } \\
\text { associated to a "big bang" opening of a new hospital in Santiago, Francisco Acevedo }\end{array}$ \\
\hline China & A novel automatic method of renal segmentation in GRF estimation, Xu Lei \\
\hline Colombia & $\begin{array}{l}\text { Modeling and simulation of ciprofloxacin pharmacokinetics: Electric circuits approach, J. } \\
\text { D. Otálvaro, A. F. Zuluaga, A. M. Hernández }\end{array}$ \\
\hline
\end{tabular}




\begin{tabular}{|c|c|}
\hline Focus Area & Title, authors, with active links \\
\hline Colombia & $\begin{array}{l}\text { Autoregressive models of electrocardiographic signal contaminated with motion arti- } \\
\text { facts: Benchmark for biomedical signal processing studies, F. A. Castaño, A. M. Hernández }\end{array}$ \\
\hline Colombia & $\begin{array}{l}\text { Parametric modeling of kinetic-kinematic polycentric mechanical knee, A. M. Cárdenas, J. } \\
\text { Uribe, A. M. Hernández }\end{array}$ \\
\hline Colombia & $\begin{array}{l}\text { Motion artifacts recognition in electrocardiographic signals through artificial neural } \\
\text { networks and support vector machines for personalized health monitoring, A. Castaño, } \\
\text { A. Hernández }\end{array}$ \\
\hline Colombia & $\begin{array}{l}\text { Learning tool for mechanical ventilation during spontaneous breathing test on patients } \\
\text { intoxicated with pesticides, M. B. Salazar Sánchez et al }\end{array}$ \\
\hline Colombia & $\begin{array}{l}\text { Optimization of spectral analysis of electrophysiological recordings of the subthalamic } \\
\text { nucleus in Parkinson' } s \text { disease: A retrospective study, S. E. Valderrama-Hincapié et al }\end{array}$ \\
\hline Colombia & $\begin{array}{l}\text { Three dimensional reconstruction and airflow simulation in a realistic model of the hu- } \\
\text { man respiratory airways, A. E. Ruiz, J. K. Aristizábal }\end{array}$ \\
\hline Colombia & $\begin{array}{l}\text { Permanent magnets to enable highly-targeted drug delivery applications: A computa- } \\
\text { tional and experimental study, M. Mercado-M et al }\end{array}$ \\
\hline Colombia & $\begin{array}{l}\text { Brain functional connectivity in Parkinsons disease - EEG resting analysis, J. Carmona, J. } \\
\text { Suarez, J. Ochoa }\end{array}$ \\
\hline Colombia & Business Opportunities in HT Projects, Mario Castañeda \\
\hline Croatia & Supporting Diabetic Patients with a Remote Patient Monitoring Systems, S. Zulj et al \\
\hline Denmark, Norway & Impedance-based monitoring for tissue engineering applications, C. Canali et al \\
\hline Ethiopia & Producing Oxygen Concentrators for Low Resource Settings, Mekdes Seyoum \\
\hline Global & $\begin{array}{l}\text { Development of an Innovative regulated Affordable Uterine Balloon Tamponade for the } \\
\text { Management of Post-partum Hemorrhage, Elizabeth Abu-Haydar, Chris de Villiers }\end{array}$ \\
\hline Global & How we drive innovation within medical devices, Kristoffer Gandrup-Marino, UNICEF \\
\hline Global & $\begin{array}{l}\text { A new handheld cordless thermal coagulator, W. Prendiville, S. Rengaswamy, B. Partha, P. } \\
\text { Groesbeck, Wallace Dean, Pickett Tim, Riddle Mike, Juan Felix }\end{array}$ \\
\hline Global & Safer medication administration for labor/delivery, Beth Kolko; Bradley Younggren \\
\hline Global & Enabling and scaling early detection of breast cancer in Imics, Mihir Shah, et al \\
\hline Global & $\begin{array}{l}\text { Ultra-low-cost endoscopy for gastroesophageal cancer screening in low-income coun- } \\
\text { tries, Pietro Valdastri, Joseph Norton, Simone Calo', Beatriz Plaza, Andrew Durkin, et al }\end{array}$ \\
\hline Global & $\begin{array}{l}\text { Unsupervised electronic stethoscope for childhood pneumonia diagnostic, Mohamed- } \\
\text { Rida Benissa, J. Solà, F.Hugon,P.Starkov, F.Braun, S.Manzano, C.Verjus, A.Gervaix }\end{array}$ \\
\hline Global & Field testing a neonatal phototherapy device: a novel approach, Donna Brezinski, et al \\
\hline Global & Test for management of preeclampsia, Wendy Davis, et al \\
\hline Global & Device to save postpartum-hemorrhaging women in advanced shock, M Guha, et al \\
\hline
\end{tabular}




\begin{tabular}{|c|c|}
\hline Focus Area & Title, authors, with active links \\
\hline Global & Validity of a device for jaundice screening, Anne Cc Lee, et al \\
\hline Global & CE-IT Innovation: How to Make Health Care Right, Mario Castañeda, Tom Judd \\
\hline Global & $\begin{array}{l}\text { WHO Priority Medical Devices, Adriana Velazquez Berumen; Gabriela Jimenez Moyao, Anto- } \\
\text { nio Migliori \& Natalia Rodriguez, Adham Ismael Abdel, Alejandra Velez }\end{array}$ \\
\hline Global & Appropriate digital X-ray system with eHealth services, Romain Sahli \\
\hline Global & Role of biomedical engineer in assessing medical devices, Leandro Pecchia \\
\hline Global & Challenges in TB Diagnostics, Christopher Gilpin \\
\hline Global & $\begin{array}{l}\text { The Digital Health Atlas for Inventories and Routine Registration of Digital Health In- } \\
\text { vestments, Garrett Mehl }\end{array}$ \\
\hline Global & $\begin{array}{l}\text { Global Cooperation on Assistive Technology: WHO Priority Assistive Products List, } \\
\text { Emma Tebbutt }\end{array}$ \\
\hline Global & Essential Resources for (Emergencies and) emergency care, Teri Reynolds \& Ian Norton \\
\hline Global & The role of biomedical engineers, James Goh \\
\hline Global & Innovative appropriate technologies for low resource settings, Adriana Velazquez \\
\hline Global & Access to medical devices for Universal Health Coverage and SDGs, Adriana Velazquez \\
\hline Global & 2014: WHO medical device list for Ebola care, Adriana Velazquez \\
\hline Global & WHO Technical Specifications for Oxygen Concentrators, 2015, Adriana Velazquez \\
\hline Global & Quick \$2 test reveals if you caught a superbug in hospital, Hakho Lee, BME MGH, Boston \\
\hline India & GANDHI: global affordable need driven health innovations, Prashant Jha \\
\hline India & Hypothermia alert device: saving newborn lives, Ratul Narain; Gini Morgan \\
\hline India & $\begin{array}{l}\text { Novel Technology Policy: Integrating Service Delivery to Industry Promotion, Jitendar } \\
\text { Sharma }\end{array}$ \\
\hline India & Preventing apneas of prematurity, Ratul Narain; Gini Morgan \\
\hline India & Remote monitoring for critical infants, Ratul Narain; Gini Morgan \\
\hline India & $\begin{array}{l}\text { MoH "Andhra Med Tech Zone" administering new medical devices manufacturing park, } \\
\text { Jitendar Sharma }\end{array}$ \\
\hline India & MoH Innovations project, WHO 2GFMD, Jitendar Sharma, 2013 \\
\hline
\end{tabular}




\begin{tabular}{|c|c|}
\hline Focus Area & Title, authors, with active links \\
\hline Italy & Current and Future Trends in the HTA of Medical Devices, Oriana Ciani et al \\
\hline Italy & HTA of a Large Tablet System in Digital Pathology, Daniele Giansanti et al \\
\hline Italy & Rapid Clinical Evaluation of Robotic Surgery, Stefano Gidaro \& Luca Radice, 2016 \\
\hline Macedonia, Haiti, China & $\begin{array}{l}\text { CED Role in Linking Global HT Innovation and Standards: From the Research Lab to the } \\
\text { Bedside, Yadin David, Fred Hosea, Tom Judd }\end{array}$ \\
\hline Malaysia & Biomechanics of Long Distance Cycling of a Transtibial Amputee, Azman Hamid \\
\hline Mexico & $\begin{array}{l}\text { Semi Active Hand Orthosis, R. Itzel Flores-Luna, Ruben Valenzuela-Montes, David De-Jesus- } \\
\text { Cruz, Hanna Garcia-Guerra, Alvaro Ayala Ruiz, Mariano Garcia del Gállego }\end{array}$ \\
\hline Peru & Heavy-Metals Point of Care Detection HT to improve care, Herb Voigt, Fred Hosea \\
\hline Senegal & $\begin{array}{l}\text { Oxygen generators type PSA: solution for the supply of oxygen in Senegal, Awa Ndiaye } \\
\text { Ep Diouf }\end{array}$ \\
\hline Senegal & Innovative Diagnostics for Infectious Diseases, Catharina Boehme \\
\hline South Africa & $\begin{array}{l}\text { Medical device innovation-Local production of medical devices in Africa: characterizing } \\
\text { the landscape and assessing feasibility, Mladen Poluta }\end{array}$ \\
\hline Tanzania & $\begin{array}{l}\text { Maternal Child Health medical devices: potential impact of disruptive technology in } \\
\text { rural Tanzania, Mbuyita, Mbaruku, et al, }\end{array}$ \\
\hline Uganda, India & $\begin{array}{l}\text { Cross Border Learning: Catalyzing Medical Technology Innovation with LMICs, Alexis } \\
\text { Steel, Molly Ward }\end{array}$ \\
\hline UK & $\begin{array}{l}\text { Automating the diagnosis of Childhood Pneumonia, Elina Naydenova, Climent Casals- } \\
\text { Pascual, Thanasis Tsanas, Maarten De Vos }\end{array}$ \\
\hline UNICEF & Medical Devices for Maternal, Neonatal and Child Care, Paul LaBarre \\
\hline Uruguay & $\begin{array}{l}\text { Clinical Engineering driving new public hospital design \& construction, Franco Simini, } \\
2016\end{array}$ \\
\hline WHO & WHO HT Innovations for Low Resource Countries, Adriana Velazquez \\
\hline
\end{tabular}




\begin{tabular}{|c|c|}
\hline Focus Area & Title, authors, with active links \\
\hline Africa & Medical Devices Situation in the Africa Region, Stanislav Kniazkov \\
\hline Albania & HTM improves high technology diagnostics access, Ledina Picari \\
\hline Argentina & HT improving Provincial Access, 2015, German Giles \\
\hline Australia \& Canada & Using Telehealth to improve Diabetes care, E. Sloane, N. Wickramasinghe, S. Goldberg \\
\hline Brazil & $\begin{array}{l}\text { Evaluation of production capacity, the healthcare coverage and the access of computer- } \\
\text { ized tomography imaging in the Brazilian Public Health System, Diana Lima et al }\end{array}$ \\
\hline Brazil & Distribution of mammographs by macroregion of Brazil, Ana Claudia Patrocinio \\
\hline Brazil & $\begin{array}{l}\text { The Role of Clinical Engineers for the Management of Healthcare Technologies in a } \\
\text { Hospital Network, Eduardo Jorge }\end{array}$ \\
\hline China & $\begin{array}{l}\text { Survey of Prolonged Mechanical Ventilation in Intensive Care Units in Mainland China, } \\
\text { Li J et al }\end{array}$ \\
\hline Cuba & $\begin{array}{l}\text { A Telemedicine System to follow-up the Evolution of Chronic Diseases in the Commu- } \\
\text { nity, R.I. Gonzalez-Fernandez et al }\end{array}$ \\
\hline Denmark & The mobile laboratory: bringing high-quality testing, to the patient, Susanne Andresen \\
\hline Global & $\begin{array}{l}\text { Market Dynamics: Supporting Country Decision- Making on Medical Devices, Ray } \\
\text { Cummings }\end{array}$ \\
\hline Global & $\begin{array}{l}\text { Equipment Planning, Safety and Maintenance: Planning of Medical Imaging Services in } \\
\text { Rural Health Centers, Cari Borrás, Mario Forjaz Secca, Yadin David, (part2) }\end{array}$ \\
\hline Global & Surgery: indispensable interventions are not readily available, Walt Johnson \\
\hline Global & International Atomic Energy Agency: Roadmap to Cancer-Free World, Rajiv R Prasad \\
\hline Global & $\begin{array}{l}\text { The importance of laboratory and pathology for a good diagnosis and treatment, need } \\
\text { for recognition and availability, Jagdish Butany }\end{array}$ \\
\hline Global & The Rise of Telehealth, Yadin David et al \\
\hline Global & Linear Accelerators Case Studies, Marcos Martins \\
\hline India & $\begin{array}{l}\text { Prioritisation of medical devices and diagnostics in India, Yogita Kumar, Gupta Madhur, } \\
\text { Ameel Mohammed }\end{array}$ \\
\hline India & Ministry of Health $(\mathrm{MoH})$ Mobile Medical Units, Jitendar Sharma \\
\hline India & MoH Free Diagnostics Service Initiative, Jitendar Sharma \\
\hline India & MoH National Dialysis Program, Jitendar Sharma \\
\hline India & Telemedicine Reducing Blindness in South India, Niranjan Khambete \\
\hline
\end{tabular}




\begin{tabular}{l|l}
\hline \multicolumn{1}{c|}{ Focus Area } & \multicolumn{1}{c}{ Title, authors, with active links } \\
\hline Kenya & Improving Universal Health Coverage Kenya PPP example, Gisela Abbam, Farid Fezoua \\
\hline Mexico & $\begin{array}{l}\text { CENETEC - National inventory of high-tech medical equipment as HTM tool for strategy } \\
\text { planning, Roberto Ayala }\end{array}$ \\
\hline $\begin{array}{l}\text { Mozambique, Tanza- } \\
\text { nia, Malawi, Togo, DR } \\
\text { Congo }\end{array}$ & Global Healthcare Telemedicine, Michelangelo Bartolo \\
\hline $\begin{array}{l}\text { Paraguay } \\
\text { Romania }\end{array}$ & $\begin{array}{l}\text { Innovative telediagnosis technology for universal coverage in remote locations without } \\
\text { access to specialists, Pedro Galvin }\end{array}$ \\
\hline $\begin{array}{l}\text { Slovakia } \\
\text { Selemonitoring Systems and Technologies for Independent Life of Elderly, S. B. Sebesi }\end{array}$ \\
\hline $\begin{array}{l}\text { Somalia, Afght, Lebanon, } \\
\text { and Iraq }\end{array}$ & $\begin{array}{l}\text { Telemedicine and mHealth System for Complex Management in T1DM and T2DM Pa- } \\
\text { tients: Results of } 6 \text { Months Study, Fedor Lehocki, Tomas Bacigal }\end{array}$ \\
\hline Syria & Hemail \\
\hline WHO & WHO Cancer Care Initiative 2015-2016, Adriana Velazquez et al \\
\hline
\end{tabular}




\begin{tabular}{|c|c|}
\hline Focus Area & Title, authors, with active links \\
\hline $\begin{array}{l}\text { Benin, Burkina Faso, Bu- } \\
\text { rundi, Cameroon, DRC, } \\
\text { Ethiopia, the Gambia, } \\
\text { Ghana, Ivory Coast, Kenya, } \\
\text { Nigeria, South Africa, Tan- } \\
\text { zania, Uganda, Zambia }\end{array}$ & $\begin{array}{l}\text { THET NGO \& South Africa enhancing } 15 \text { African HTM societies, Anna Worm \& Mladen } \\
\text { Poluta }\end{array}$ \\
\hline Australia & In-house Endoscopy support, 2016, Anne-Louise Smith \\
\hline Bangladesh & $\begin{array}{l}\text { Clinical Engineering Approach to Improve Healthcare Technology Management for En- } \\
\text { hancing Healthcare Delivery System in Middle Income Countries, A. Hossain et al }\end{array}$ \\
\hline Benin & $\begin{array}{l}\text { Evaluation of medical devices in Benin, Charles Pascal Soroheye, Adjaratou Seidou Maliki, } \\
\text { Marc Myszkowski }\end{array}$ \\
\hline Benin & $\begin{array}{l}\text { Maintenance management of medical devices in Benin: The case of Papané Hospital, } \\
\text { Charles Pascal Soroheye et al }\end{array}$ \\
\hline Bhutan & Bhutan Health Technology Management (HTM) and HTA 2015, Tashi Penjore \\
\hline Bosnia \& Herzegovina & $\begin{array}{l}\text { Testing of dialysis machines in healthcare institutions in Bosnia and Herzegovina, Lejla } \\
\text { Gurbeta, Berina Alic, Zijad Dzemic, Almir Badnjevic }\end{array}$ \\
\hline Botswana & Using HTM to improve care delivery, Bonnie Tlhomelang \\
\hline Brazil & $\begin{array}{l}\text { Impact of clinical engineering in primary healthcare, Priscila Avelar, Renato Garcia, Carlos } \\
\text { Alberto Silva }\end{array}$ \\
\hline Brazil & $\begin{array}{l}\text { Logistics of medical devices for indigenous health care attending in remote sites at Bra- } \\
\text { zilian amazon rain forest, Ryan Ferriera et al }\end{array}$ \\
\hline Brazil & GETS System on CE-HTM, Jose Bassani \\
\hline Brazil & Medical device manuals analysis using heuristic evaluation, J.C. Carneiro et al \\
\hline Brazil & Proposed Calibration of Apheresis Equipment, A.S. Anderson et al \\
\hline Brazil & Maternal Fetal Simulator, L.R. Rodrigo et al \\
\hline Brazil & $\begin{array}{l}\text { Evaluation of Sphygmomanometers: comparison between manual and digital measure- } \\
\text { ment, Sousa et al }\end{array}$ \\
\hline Brazil & Hospital Maintenance Management, A.S. Forte, J.E.Neto \\
\hline Brazil & $\begin{array}{l}\text { Study involving X-Ray Tube Life spam in Computed Tomography Equipment, Petrick } \\
\text { Marcellus de Victorio et al }\end{array}$ \\
\hline Brazil & HTA Applied to HTM through Clinical Engineering, Santos \\
\hline Burkina Faso & $\begin{array}{l}\text { The problem of acquisition and maintenance of biomedical equipment in Burkina Faso, } \\
\text { Zida Ouambi Emmanuel }\end{array}$ \\
\hline Chile & Activities of Clinical Engineering in the University of Valparaiso, Guillermo Avendano \\
\hline Chile & The Chilean Navy Hospitals 15 years of CE, Francisco Acevedo \\
\hline
\end{tabular}




\begin{tabular}{|c|c|}
\hline Focus Area & Title, authors, with active links \\
\hline China & Preventive Maintenance of Fetal Monitors, LE He-qing \\
\hline China & $\begin{array}{l}\text { The Survey of } 3 \text { Departments in Guangdong Province Under New Regulations, Yang } \\
\text { Shaozhou }\end{array}$ \\
\hline China & Impact of national CE Certification on Health Technology, Zhou Dan \\
\hline Colombia & CE and impact on financial management of the hospital, Paula Berrio \\
\hline Colombia & $\begin{array}{l}\text { Estimation of the optimal maintenance frequency of medical devices: A Monte Carlo } \\
\text { simulation approach, Antonio Miguel Cruz et al }\end{array}$ \\
\hline Colombia & $\begin{array}{l}\text { Teaching maintenance of medical devices in simulation centers: a pilot study, Daniel Ale- } \\
\text { jandro Quiroga Torres et al }\end{array}$ \\
\hline Costa Rica & $\begin{array}{l}\text { Clinical Engineering - Health Technology Management (HTM) key areas of challenge } \\
\text { and progress in Costa Rica, Gabriela Murillo }\end{array}$ \\
\hline Costa Rica & HTM in Costa Rica, G Murillo, M. Ingeana, (part2) \\
\hline Cuba & Cuba Health Technology Management, Jorge Castro Medina \\
\hline Dominica & Health Technology Management in Dominica, R. Williams \\
\hline Ecuador & $\begin{array}{l}\text { Development of Biomedical Engineering in the Honorable Junta de Beneficencia of } \\
\text { Guayaquil, Freddy Matamoros }\end{array}$ \\
\hline El Salvador & Health Technology Management in El Salvador, Juarez S. \\
\hline Ethiopia & $\begin{array}{l}\text { Managing Successful Medical Device Warranty Period Maintenance, Demeru Yeshitla } \\
\text { Desta, Tegbar Yigzaw Sendeke, Sharon Kibwana, Mihereteab Teshome Tebeje }\end{array}$ \\
\hline Ethiopia & $\begin{array}{l}\text { Strengthening Utility and Maintenance of Medical Devices, Demeru Yeshitla Desta, Sharon } \\
\text { Kibwana, Firew Ayalew, Ismael Cordero }\end{array}$ \\
\hline Ghana & CMBES HTM Donations Study, 2015, Bradley, Yoon, Zahedi, Adusei-poku, Bill Gentles \\
\hline Global & $\begin{array}{l}\text { Medical device ownership models and maintenance contracting approaches, Lisa Smith, } \\
\text { Michael Ruffo }\end{array}$ \\
\hline Global & $\begin{array}{l}\text { The Missing Link: The Role of BMETs Throughout the HTM Lifecycle, Anna Worm, THET; } \\
\text { Ismael Cordero, Gradian }\end{array}$ \\
\hline Global & Global HTM Update 2011, Binseng Wang et al \\
\hline Global & Global HTM Update 2015, T. Judd, S. Calil, A. Hernandez, B. Gentles \\
\hline Global & IFMBE CED Development of e-Courses for HTM training 2015-2016, Ernesto Iadanza \\
\hline Global & Orbis International Global HTM Training, Ismael Cordero, (part2) \\
\hline Global & ACCE Global HTM Seminars, 2013 2GFMD, Antonio Hernandez et al \\
\hline Haiti & Using HTM to improve care delivery, Monette Valliere, Jean Chery, (part2) \\
\hline
\end{tabular}




\begin{tabular}{|c|c|}
\hline Focus Area & Title, authors, with active links \\
\hline Italy & $\begin{array}{l}\text { Launch of the new WHO Collaborating Centre for Research and Training in CE and HTM, } \\
\text { Paolo Lago }\end{array}$ \\
\hline Italy & $\begin{array}{l}\text { A Novel Approach to Improve the Technical Maintenance of Biomedical Equipment, } \\
\text { Daniele Bibbo et al }\end{array}$ \\
\hline Jamaica & Health Technology Management in Jamaica, 2010, Keith Richards \\
\hline Kenya & MoH ophthalmic equipment support, Philip Anyango, Mary Nguri \& Joseph Rugut \\
\hline Kenya & MoH Device HydroCarbon Refrigeration Training BMETs, J. Rugut \\
\hline Kosovo & HTM in Kosovo, 2010, Agron Boshnjaku S. Ramiqi S, K. Hashani, (part2) \\
\hline Kyrgyzstan & HTM in Kyrgyzstan, 2010, Kazbek Agibetov, (part2) \\
\hline Laos & HTM in Laos, 2GFMD 2013, Thanom Insal \\
\hline Lebanon & HTM Implementation at Saint George Hospital - Lebanon, Riad Farah \\
\hline Lebanon & Medical Devices Repair/Replacement Algorithm Model, Riah Farah \\
\hline Mexico & Decodifying HTM in Mexican Private Hospitals, Luis Fernandez \\
\hline Nigeria & Key areas of challenge and progress of CE-HTM in Nigeria, Bukola Esan \\
\hline Paraguay & Health Technology Management in Paraguay, Pedro Galvan, (part2) \\
\hline Peru & $\begin{array}{l}\text { Fostering Clinical Engineering \& HTM in Developing Countries: Alignment and Effec- } \\
\text { tiveness in Peruvian Health Sector, Rossana Rivas }\end{array}$ \\
\hline Puerto Rico & Health Technology Management update in Puerto Rico, Oscar Misla, (part2) \\
\hline Romania & Prioritization of Medical Devices for Maintenance Decisions, S. Taghjpour et al \\
\hline Rwanda & Medical device technician training, A. Worm, Mpamije Tonkin, Mol, Kasaro \\
\hline Saudi Arabia & Creation of Health Technology Technical E-Library, Salah Alkhallagi \\
\hline Senegal & $\begin{array}{l}\text { Maintenance of medical devices and quality management in Senegal, Dr. Mamadou Sow, } \\
\text { Senegal, WHO 2GFMD }\end{array}$ \\
\hline Sierra Leone & $\begin{array}{l}\text { Immediate impacts of inventory on procurement, donations, maintenance and use of } \\
\text { medical equipment, Kabia, Johnson, Ministry of Health, WHO 2GFMD, } 2013\end{array}$ \\
\hline South Africa & Math Model for Reliable Maintenance of Medical Equipment, Baset Khalaf, 2015, (part2) \\
\hline Sub-Sharan Africa & $\begin{array}{l}\text { The status of medical equipment in Sub-Sahara Africa, Anna Worm, Theogene Nama- } \\
\text { hungu, Harold Chimphepo, Charles P. Soroheye }\end{array}$ \\
\hline
\end{tabular}




\begin{tabular}{|c|c|}
\hline Focus Area & Title, authors, with active links \\
\hline Sudan & Health Technology Management in Sudan, Emad Edin Mohamed Hassan, (part2) \\
\hline Taiwan & Medical Devices Troubleshooting, KP Lin \\
\hline Taiwan & $\begin{array}{l}\text { The Benefit of In-Hospital Clinical Engineer Services for Medical Devices Maintenance, } \\
\text { Mei-Fen Chenet al }\end{array}$ \\
\hline Taiwan & $\begin{array}{l}\text { Taiwan: An IM Strategy for In-House CE Department Based on Equipment Service Life- } \\
\text { Cycle Model, Chia-Hung Chien et al }\end{array}$ \\
\hline Tanzania & Health Technology Management in Tanzania, Y Mkwizu \& R Masanja, (part2) \\
\hline Tanzania, Switzerland & $\begin{array}{l}\text { Building management capacities for essential equipment in Tanzania, WHO 2GFMD, } \\
\text { 2013, Reinhold Werlein, Swiss Tropical and Public Health Institute }\end{array}$ \\
\hline The Gambia & Medical Research Council HTM Unit, Anna Kah, Ebrima Nyassi \\
\hline Togo & $\begin{array}{l}\text { The governance problem in medical equipment donation projects: Case of Togo, WHO } \\
2 \text { GFMD, 2013, Komi Agbeko Tsolenyanu, NGO Association for Maternal, Neonatal and Child } \\
\text { Health }\end{array}$ \\
\hline Uganda & Using HT Policy and HTM to improve MoH care delivery, Sitra Mulepo, Kataaha Edward \\
\hline UK & $\begin{array}{l}\text { Apprenticeship model for clinical engineering workforce development, Abdul Basit, Mal- } \\
\text { colm Birch }\end{array}$ \\
\hline USA & Kaiser Permanente Clinical Engineering Staffing Best Practices 2015, Chris Ewing \\
\hline Zambia & $\begin{array}{l}\text { Medical equipment maintenance personnel and training in Zambia; S. Mullally, T. Bbuku, } \\
\text { G. Musonda } 2012\end{array}$ \\
\hline
\end{tabular}




\begin{tabular}{|c|c|}
\hline Focus Area & Title, authors, with active links \\
\hline Africa & $\begin{array}{l}\text { The potential power of sub-Saharan Africa professional associations for biomedical/ } \\
\text { clinical engineering professionals, Anna Worm et al }\end{array}$ \\
\hline Africa - 18 countries & $\begin{array}{l}\text { The (improved) status of medical equipment in sub-Sahara Africa HTM: A. Worm, L. } \\
\text { Jones, T. Namahungu, H. Chimphepo, P. Soroheye }\end{array}$ \\
\hline Albania & $\begin{array}{l}\text { Regulation, standards and market surveillance of medical devices and systems in Alba- } \\
\text { nia, Ledina Picari }\end{array}$ \\
\hline Albania & MoH Health Technology (HT) Unit device legislation, Ledina Picari, 2016 \\
\hline Argentina & Present and Future of Clinical Engineering in Argentina, German Giles, Marcelo Lencina \\
\hline Asia Pacific & Status of Biomedical Engineering education in the Asia Pacific, KP Lin et al \\
\hline Bangladesh & Biomedical and clinical engineering development, Md Ashrafuzzaman et al \\
\hline Bangladesh & $\begin{array}{l}\text { Necessity of Clinical Engineering to Regulate the Medical Devices in Middle Income } \\
\text { Countries, Anwar Hossain }\end{array}$ \\
\hline $\begin{array}{l}\text { Bosnia and } \\
\text { Herzegovina }\end{array}$ & Medical devices in legal metrology framework, Lejla Gurbeta, Almir Badnjevi $\square$ \\
\hline Brazil & $\begin{array}{l}\text { Analysis of the Curriculum of Postgraduate Courses in Clinical Engineering in Brazil, An- } \\
\text { derson A. Ramos et al }\end{array}$ \\
\hline Brazil & $\begin{array}{l}\text { Application of multiparameter method as an assistance to the evaluation of the need } \\
\text { for replacement of medical equipment, M.A. Marciano, E.K. Souza }\end{array}$ \\
\hline Brazil & $\begin{array}{l}\text { Assistant Multi-Parametric Method to the Selection in the Process of Incorporation of } \\
\text { Hospital Equipment, M.A. Marciano }\end{array}$ \\
\hline Brazil & $\begin{array}{l}\text { International Standards for Medical Device and The U.S. Food and Drug Administration, } \\
\text { R.G. Fernandes }\end{array}$ \\
\hline Brazil & Computed Tomography scanners productivity and examinations times, R.P. Santos et al \\
\hline Brazil & $\begin{array}{l}\text { Defibrillators in locations with a high concentration/movement of people in Bauru/Bra- } \\
\text { zil, A.S. de Melo et al }\end{array}$ \\
\hline Brazil & $\begin{array}{l}\text { FDA Internationalization Under the Aspect of Medical Device Standards, R.G. Fernandes, } \\
\text { S.J. Calil }\end{array}$ \\
\hline Brazil & $\begin{array}{l}\text { Medical equipment acquisition methodology in public procurement process, J. Martins } \\
\text { et al }\end{array}$ \\
\hline Brazil & $\begin{array}{l}\text { Cost Estimate Methodology in procurement processes of Medical Equipment, V. O. Fa- } \\
\text { gundes, R. Zaniboni, R. Garcia }\end{array}$ \\
\hline Brazil & $\begin{array}{l}\text { Study of Medical Device Purchasing Cycles through Temporal Series Analysis, J. C. Guer- } \\
\text { rero, J. H. García, A. M. Hernández }\end{array}$ \\
\hline Brazil & RENEM - MoH HT list driving national investment, Murilo Conto \\
\hline Cameroon & Development of the National Healthcare Technology Policy for Cameroon, J. Riha \\
\hline Cameroon & $\begin{array}{l}\text { Improvement in the use of medical devices and capitalization of investments in the HT } \\
\text { sector in Cameroon, 2010, Vincent Ngaleu-Toko }\end{array}$ \\
\hline Canada & Clinical Engineering/HTM in Canada, Mario Ramirez \\
\hline
\end{tabular}




\begin{tabular}{|c|c|}
\hline Focus Area & Title, authors, with active links \\
\hline Chile & University of Valpariso Health Technology leadership, Cristian Diaz \\
\hline China & Clinical Engineering in China, Bao Jiali, Zhu Chaoyang \\
\hline China & HTM as key health planning discipline, Guanxin Gao \\
\hline Colombia & $\begin{array}{l}\text { Integrated model of universities to promote clinical engineering, Nelson Escobar, Javier } \\
\text { Camacho, Javier García, Juan Barreneche, Beatriz Galeano, Mario Castañeda }\end{array}$ \\
\hline Colombia & $\begin{array}{l}\text { Interuniversity model of cooperation for the development of Clinical Engineering in Co- } \\
\text { lombia, Beatrix Galeano }\end{array}$ \\
\hline Colombia & $\begin{array}{l}\text { Methodology Design for Biomedical Technology Replacement Planning, D. M. } \\
\text { Torres-Velez }\end{array}$ \\
\hline Colombia & Regional Nodes of Colombian Clinical Engineers, Andrea Garcia \\
\hline Colombia & $\begin{array}{l}\text { Identifying the needs in the integration of disciplines in the hospital infrastructure man- } \\
\text { agement in Colombia, M. Madroñal Ortiz, B. Galeano Upegui, N. Escobar Mora, L. Cruz Parra, } \\
\text { I. Rios Cuartas }\end{array}$ \\
\hline Colombia & HT Regulation, Policy, Management, 2015, Andrea García Ibarra, Rojas Morales, (part2) \\
\hline Colombia & $\begin{array}{l}\text { Clinical Engineering for non-engineers: acquisition of medical equipment, 2011, Tatiana } \\
\text { Molina }\end{array}$ \\
\hline Cuba & $\begin{array}{l}\text { Trading barriers in the medical devices industry. Are these barriers hindering the de- } \\
\text { velopment of this sector in Cuba? Y. Chaveco Salabarria, J. C. Rubio Romero, R. M. Guerra } \\
\text { Bretaña }\end{array}$ \\
\hline Czech Republic & $\begin{array}{l}\text { Hospital Based HTA - Implementation for the Czech Republic, Ivana Kubátová, Veronika } \\
\text { MatloDová }\end{array}$ \\
\hline Ethiopia & Using HT Policy and HTM to improve care delivery, Mulugeta Mideksa, 2015 \\
\hline $\begin{array}{l}\text { EU (28 Member States), } \\
\text { EFTA/EEA: Norway, } \\
\text { Liechtenstein, Iceland; } \\
\text { Turkey; Switzerland }\end{array}$ & The Regulation of medical devices in the European Union, Carlo Pettinelli \\
\hline Ghana & Clinical Engineering in Ghana, Nicholas Adjabu \\
\hline Ghana, Canada & CMBES Donations Project, 2015, Nicolas Adjabu, John Zienna, Bill Gentles \\
\hline Global & IFMBE/CED and Global CE-HTM Evidence Based Results, Yadin David, Ernesto Iadanza \\
\hline Global & IFMBE/CED Role in Global BME/CE recognition, James Goh, Ernesto Iadanza \\
\hline Global & Global CE-HTM Success Stories, Yadin David, Tom Judd \\
\hline Global & $\begin{array}{l}\text { Technical characterization of appropriate medical equipment, Maurice Page, Matthieu } \\
\text { Gani, Mélanie Amrouche, Robin Walz, Blanc-Gonnet \& Barbara Comte } \\
\end{array}$ \\
\hline Global & $\begin{array}{l}\text { MSF medical equipment framework, Gabriela Jimenez Moyao, Oscar Rodriguez, Tom Lauwaert, } \\
\text { Jean Claude Tewa, Belgium; Benoit Pierre Ligot, Paul Damien Chateau, MSF, France; Hugues Gaertner, } \\
\text { MSF, Spain; Malcom Townsend, MSF, Switzerland; Lizette Van De Kamp, Sean King, MSF, Netherlands }\end{array}$ \\
\hline
\end{tabular}




\begin{tabular}{|c|c|}
\hline Focus Area & Title, authors, with active links \\
\hline Global & Assessment of medical devices in low-income settings, L. Pecchia, N. Pallikarakis \\
\hline Global & $\begin{array}{l}\text { The AHWP Playbook for Implementation of a Health Technology Regulatory Frame- } \\
\text { work, An Overview, Ms. Joanna Koh et al }\end{array}$ \\
\hline Global & Global Atlas of Medical Devices, Adriana Velazquez \\
\hline Global & $\begin{array}{l}\text { Medical Devices for universal health coverage and sustainable development, Marie-Paule } \\
\text { Kieny }\end{array}$ \\
\hline Global & $\begin{array}{l}\text { The Book, Human Resources for Medical Devices, the Role of the Biomedical Engineer, } \\
\text { Adriana Velazquez }\end{array}$ \\
\hline Global & $\begin{array}{l}\text { National medical equipment policies and planning for universal health coverage, Rob- } \\
\text { erto Ayala }\end{array}$ \\
\hline Global & $\begin{array}{l}\text { Improving medical equipment donations: contribution of NGO Humatem, Cathy } \\
\text { Blanc-Gonnet }\end{array}$ \\
\hline Global & Health Technology Management Initiatives, Ernesto Iadanza \\
\hline Global & Health Technology Assessment of innovative medical devices, Iñaki Gutiérrez-Ibarluzea \\
\hline Global & $\begin{array}{l}\text { IFMBE/Clinical Engineering Division projects for the advancement of the profession of } \\
\text { clinical engineering, Ernesto Iadanza }\end{array}$ \\
\hline Global & The importance of Technical Specifications, Adriana Velazquez \\
\hline Global & The Role of HTM to the Universal Health Coverage, P. Galvan et al \\
\hline Global & $\begin{array}{l}2009 \text { WHO database of biomedical/clinical engineering teaching units and associations } \\
\text { worldwide, Saide Calil }\end{array}$ \\
\hline Global & Global HT Disaster Preparedness, Yadin David, Fred Hosea, (part2) \\
\hline Global & Latin American \& Caribbean Health Technology Training, 2013, Antonio Hernandez \\
\hline Global & Role of IFMBE in medical equipment in developing countries, Worm, Linnenbank \\
\hline Global & $\begin{array}{l}\text { The importance of establishing a national policy for infrastructure, Africa Health, Andrei } \\
\text { Issakov }\end{array}$ \\
\hline Global & Need for Undergraduate Clinical Engineering Education, 2015, Herb Voigt \\
\hline Global & MAKING IT WORK: Managing medical equipment in low-resource settings video, THET \\
\hline Global & $\begin{array}{l}\text { The role of HTM in WHO, to support access to medical devices for Universal Health Cov- } \\
\text { erage and achievement of SDGs, Adriana Velazquez, (part2, part3) }\end{array}$ \\
\hline Global & IFMBE HTA Division Filling the gap between HTA and HTM, Leandro Pecchia \\
\hline Global & $\begin{array}{l}\text { Global Health Technology Equity: How Emerging CE-HTM Leaders Can Help, Antonio } \\
\text { Hernandez, Tom Judd }\end{array}$ \\
\hline
\end{tabular}




\begin{tabular}{|c|c|}
\hline Focus Area & Title, authors, with active links \\
\hline Greece & $\begin{array}{l}\text { Medical equipment management, Nicolas Pallikarakis, Institute of Biomedical Technology, } \\
\text { Greece }\end{array}$ \\
\hline India & $\begin{array}{l}\text { Generic Specifications for Medical Equipment in Developing Countries, S.B.Sinha, } \\
\text { A.R.Gammie and P.J.Mellon }\end{array}$ \\
\hline India & MoH HTM via Public Private Partnership, 2015, Jitendar Sharma \\
\hline $\begin{array}{l}\text { India, Indonesia, } \\
\text { Thailand }\end{array}$ & South East Asia Regional Perspective, Madhur Gupta \\
\hline Indonesia & Development of biomedical engineering education in Indonesia, Cholid Badri \\
\hline Italy & $\begin{array}{l}\text { The Italian Clinical Engineers Association: a success story, Stefano Bergamasco, Paolo } \\
\text { Lago, Lorenzo Leogrande, Umberto Nocco }\end{array}$ \\
\hline Italy & $\begin{array}{l}\text { Assessing the impact of a CIS/PACS technology for a cardiology department using QFD } \\
\text { methodology, Alessio Luschi, Laura Caltagirone, Claudio Mondovecchio, Roberto Miniati, Er- } \\
\text { nesto Iadanza }\end{array}$ \\
\hline Italy & Model national CE society and impact on legislation, Paolo Lago, Lorenzo Leogrande \\
\hline Japan & Roles of Clinical Engineering in medical device development, Hiroki Igeta et al \\
\hline Japan & The Business Operations of CEs, Roles and Certifications, Jun Yoshioka \\
\hline Kenya & Using HTM to improve MoH care delivery, Philip Anyango Amoko, (part2) \\
\hline Kyrgyzstan, Albania & HT characteristics of countries in the WHO European region, Tifenn Humbert \\
\hline Latin America & $\begin{array}{l}\text { The status of Biomedical Engineering (BME) programs in Latin America, Martha Zequera } \\
\text { Díaz, A. P. Koch }\end{array}$ \\
\hline Mexico & Health Technology Project Value Chain, Andrade Bravo Ignacio \\
\hline Mexico & $\begin{array}{l}\text { Opportunities of the Mexican Biomedical Engineering Society to influence and adopt } \\
\text { Clinical Engineering in Mexico, Elliot Vernet }\end{array}$ \\
\hline Mexico & CENETEC- MoH HT Unit creates nation-wide HTM capacity, Roberto Ayala \\
\hline Mexico & $\begin{array}{l}\text { HTA, HT Regulation, HTM to improve care delivery, Cardenas, de Alba, Orencio, Moreno, } \\
\text { (part2) }\end{array}$ \\
\hline Moldova & $\begin{array}{l}\text { Medical Devices Management Strategy in the Republic of Moldova, V. Sontea, S. Mor- } \\
\text { goci, Gh. Turcanu, C. Pislaru }\end{array}$ \\
\hline Nigeria & Using HT Policy and HTM to improve care delivery, Bukola Esan \\
\hline Peru & $\begin{array}{l}\text { Improving Emergency Preparedness through Hybrid Interactive Training, T. Clark, R. Ri- } \\
\text { vas, Y. David }\end{array}$ \\
\hline Peru & A Comprehensive System for HTM, L. Vilcahuaman, M. Cordova, J. Kalafatovich, R. Rivas \\
\hline Peru & $\begin{array}{l}\text { MoH \& National Institute of Health HT Unit care improvement strategies, Rossana Rivas, } \\
\text { Luis Vilcahuaman }\end{array}$ \\
\hline
\end{tabular}




\begin{tabular}{|c|c|}
\hline Focus Area & Title, authors, with active links \\
\hline Peru & Collaborative HT partnerships to improve care delivery 2015, Rossana Rivas \\
\hline Portugal & Technology decision-making process: MRI purchase in Portugal, Maria Maia \\
\hline Romania & Knowledge about materiovigilance in Cluj-Napoca, Romania, Simona Maria Mirel \\
\hline $\begin{array}{l}\text { Rwanda, Benin, Cam- } \\
\text { eroon, Guinea, Nigeria, } \\
\text { Sierra Leone }\end{array}$ & The odyssey of an HTM Expert, Mboule, Cameroon \\
\hline Sierra Leone, Canada & $\begin{array}{l}\text { Sierra Leone / Canada: Transnational Donations of Medical Equipment, Dinsie Williams, } \\
\text { Jillian Kohler, University of Toronto }\end{array}$ \\
\hline Singapore & Global BME Education Programs, 2016, Siew-Lok Toh \\
\hline South Africa & Health Technology Management in the African Continent, Mladen Poluta \\
\hline Suriname & Using HTM to improve care delivery, Gillian Jie \\
\hline Taiwan & Intern programs of biomedical engineering education, Kangping Lin; Tsai, Chenglun \\
\hline Taiwan & $\begin{array}{l}\text { BME/Clinical Engineering (CE) Role for Policy Implementation of Medical Equipment re- } \\
\text { garding Post-Market Surveillance in Health Systems, KP Lin, (part2) }\end{array}$ \\
\hline Taiwan & Accreditation of BME/CE in Taiwan, KP Lin, (part2) \\
\hline Turkey & $\begin{array}{l}\text { MoH HT Unit product tracking/surveillance/pricing \& Country-wide HTM Data, Ugur } \\
\text { Cunedioglu, Bilal Beceren }\end{array}$ \\
\hline Turkey & HTM improving country-wide care delivery, Bilal Beceren \\
\hline UK & $\begin{array}{l}\text { Crisis, What Crisis? How Clinical Engineers will Solve the Billion Dollar Healthcare Fund- } \\
\text { ing Gap, Daniel Clark }\end{array}$ \\
\hline UK, Global & Tropical Health Education Trust (THET) partnerships, A. Worm and Schofield \\
\hline Vietnam & $\begin{array}{l}\text { Survey of Personnel Who Are Operating, Repairing and Maintaining Medical Equipment } \\
\text { in Some Hospitals in Vietnam, 2013, Tam }\end{array}$ \\
\hline WHO & WHO HT Indicators for $\mathrm{MoH}, 2009$, Joachim Nagel et al \\
\hline WHO & WHO \& International Labor Organization discussions 2015-2017, Adriana Velazquez \\
\hline WHO AMRO & Development and initiatives of medical devices in the Americas, Alexandre Lemgruber \\
\hline WHO EMRO & $\begin{array}{l}\text { Strengthening Medical Devices Regulation in the Eastern Mediterranean Region of } \\
\text { WHO, Adham R Ismail }\end{array}$ \\
\hline
\end{tabular}




\begin{tabular}{|c|c|}
\hline Focus Area & Title, authors, with active links \\
\hline Brazil & Telerradiology network in Amazonas rainforest, Leonardo Melo, Alessandro Melo \\
\hline Brazil & Telecommunication innovation in mobile health units, Leonardo Melo, Alessandro Melo \\
\hline Brazil & Business intelligence application in health management, O.B. Souto et al \\
\hline Brazil & Geocoding dengue cases for spatial analysis, J. L. S. Lustosa et al \\
\hline Brazil & $\begin{array}{l}\text { Integration of the trans-operative information with the patient's electronic record, E. K. } \\
\text { Souza, M.A. Marciano }\end{array}$ \\
\hline Brazil & Dental Chair Unit Clinical Engineering management, G. L.O. da Fonseca, F.S. Rosa, R. Garcia \\
\hline Bulgaria, Greece & $\begin{array}{l}\text { Re-engineering a Medical Devices Management Software System: The web approach, } \\
\text { 2014, Malataras, Bliznakov et al }\end{array}$ \\
\hline China & Mobile control of risk factors of NCDs, Bao Jiali, Zhu Chaoyang, Bao Jiaming, Zheng Xiuxiu \\
\hline China & $\begin{array}{l}\text { Mutual recognition research of medical imaging remote intelligent quality control tech- } \\
\text { nology, JingXin }\end{array}$ \\
\hline Colombia & Networking from Colombian clinical engineers, Andrea Rocio Garcia Ibarra \\
\hline Colombia & $\begin{array}{l}\text { Introducing IHE (Integrating the Healthcare Enterprise) into Colombia \& Latin America, } \\
\text { 2015, Vladimir Quintero: }\end{array}$ \\
\hline Georgia & Becoming of Ubiquitous Sensors for Ubiquitous Healthcare, S. Dadunashvili \\
\hline Global & Medical device service procedures mobile application, Jean Ngoie, Kelsea Tomaino \\
\hline Global & $\begin{array}{l}\text { Use of CMMS (Computerized Medical equipment Management System) in Low Resource } \\
\text { Countries, Bill Gentles, Claudio Meirovich, Martin Raab, Jitendra Sharma }\end{array}$ \\
\hline Global & $\begin{array}{l}\text { Clinical and ICT (Information and Communication Technologies) Cybersecurity Over- } \\
\text { view and Cases, Elliot Sloane }\end{array}$ \\
\hline Global & Integrated Health Solutions to deliver value-based Healthcare, Frederic Noel \\
\hline Global & Conquering the leprosy last mile: the role of mobile-phones, Phillip Olla \\
\hline Global & $\begin{array}{l}\text { Appropriate CMMS systems - potential for health systems development, Mr. Martin } \\
\text { Raab, David Huser, Alexandre Vanobbhergen }\end{array}$ \\
\hline Global & Clinical Engineering, eHealth, and ICT Global Overview, Elliot Sloane \\
\hline Global & $\begin{array}{l}\text { Decision Support Systems: an all-around approach to healthcare management, Ernesto } \\
\text { Iadanza }\end{array}$ \\
\hline Global & $\begin{array}{l}\text { Developments in Global Clinical Engineering-Information Technology, Tom Judd, Ricardo } \\
\text { Silva }\end{array}$ \\
\hline Global & Total Cost of Ownership, Elliot Sloane \\
\hline
\end{tabular}




\begin{tabular}{|c|c|}
\hline Focus Area & Title, authors, with active links \\
\hline Global & ICT training for Health Technology, Elliot Sloane \\
\hline Global & CE: from Devices to Systems, Roberto Miniati, Ernesto Iadanza, Fabrizio Dori, Italy \\
\hline Global & On-Line HTM Training in Latin America, Tobey Clark et al, 2015 \\
\hline Global & Using Clinical Engineering CMMS to improve care delivery, Bill Gentles \\
\hline Global & Trends on Information Technology and Health Technology, Antonio Hernandez, 2015 \\
\hline Global & Medical Device and ICT Convergence, Elliot Sloane \\
\hline Greece & $\begin{array}{l}\text { Web-based medical equipment management system, Nicolas Pallikarakis, Panayiotis Mala- } \\
\text { taras, Aris Dermitzakis }\end{array}$ \\
\hline Haiti & $\begin{array}{l}\text { Evidence-based Maternal Child Health Care enabled by Health Technology, Tom Judd, } \\
\text { Lee Jacobs, Brian Birch, and Matt Jansen }\end{array}$ \\
\hline India & Using Near-Patient Data in HTM, Tracy Rausch, Yatin Mehta MD \\
\hline India & Designing MoH HTM IT systems in Developing Countries, Jitendar Sharma, Prabhat Arora \\
\hline India, USA & $\begin{array}{l}\text { Using Integrated Clinical Environment (ICE) Data for HTM (India pilot), Tracy Rausch, } \\
\text { Tom Judd }\end{array}$ \\
\hline Italy & SILAM: Integrating Laboratory IS within the Liguria Region EHR, 2014, A. Tagliati et al \\
\hline Japan & $\begin{array}{l}\text { Study on Medical Equipment Location Systems that use RFID Technology, Manabu } \\
\text { Kawabe, Yasuyuki Miwa, Takashi Kano }\end{array}$ \\
\hline Nigeria & $\begin{array}{l}\text { Developing an Appropriate and Affordable Expert System for Medical Diagnosis in De- } \\
\text { veloping Countries, 2015, K.I. Nkuma-Udah et al, (part2) }\end{array}$ \\
\hline Portugal & End-to-End QoS-Based Admission Control via Virtual Sensor Nodes, Carlos Abreu et al \\
\hline Romania & $\begin{array}{l}\text { Development of Wireless Biomedical Data Transmission and Real Time Monitoring Sys- } \\
\text { tem, C. M. Fort, S. Gergely, A. O. Berar }\end{array}$ \\
\hline $\begin{array}{l}\text { Saudi Arabia, Macedo- } \\
\text { nia, Global }\end{array}$ & $\begin{array}{l}\text { Digital hospital 21st century: you certainly can't manage it if you don't understand it, } \\
\text { WHO 2GFMD, 2013, Elliot Sloane, Tom Judd, Paul Sherman, Joseph Welch }\end{array}$ \\
\hline Slovakia & Electronic categorization of medical devices in Slovakia, Dr. Jadud, Ministry of Health \\
\hline South Africa & Medical internet of things and embedded intelligence in healthcare, Abdelbaset Khalaf \\
\hline South Africa & Wireless Body Sensor Network and ECG Android App eHealth. Abdelbaset Khalaf \\
\hline Spain, France & $\begin{array}{l}\text { Integrating an EHR Graphical User Interface into Nanoelectronic-Based Biosensor Tech- } \\
\text { nology, Ana Maria Quintero et al }\end{array}$ \\
\hline Uruguay & $\begin{array}{l}\text { CAMACUA: Low Cost Real Time Risk Alert and Location System for Healthcare Environ- } \\
\text { ments, I. Decia et al }\end{array}$ \\
\hline
\end{tabular}




\begin{tabular}{l|l}
\hline \multicolumn{1}{|c|}{ Focus Area } & \multicolumn{1}{c|}{ Title, authors, with active links } \\
\hline USA & Assessing Risk in the Kaiser Permanente CE Program, C Davis-Smith, F Painter, M Baretich \\
\hline USA & Medical Device Cybersecurity, Steve Grimes, HIMSS 2016 \\
\hline USA & Biomedical Device Integration into an Electronic Health Record, Michael Fraai \\
\hline Venezuela, Ecuador & Intelligent System for Identification of patients in Healthcare, Ricardo Silva, (part2) \\
\hline
\end{tabular}




\begin{tabular}{|c|c|}
\hline Focus Area & Title, authors, with active links \\
\hline Australia & Medical Air Mis-connections, Anne-Louise Smith, Mark McEwen, 2016 \\
\hline Brazil & $\begin{array}{l}\text { An observational study of the high incidence of false and nuisance alarms in an inten- } \\
\text { sive care unit, LG Vaz, GC Vivas }\end{array}$ \\
\hline Brazil & $\begin{array}{l}\text { Evaluation of waste disposal inadequate management from health services, Larissa Teix- } \\
\text { eira de Oliveira, Ana Claudia Patrocínio }\end{array}$ \\
\hline Brazil & $\begin{array}{l}\text { Improving Health Technology Assessment in Cold Chain by Applying Clinical and Indus- } \\
\text { trial Engineering, LFM Brito et al }\end{array}$ \\
\hline Brazil & $\begin{array}{l}\text { Improving Operational Reliability in Medical Washer Disinfector with the Use of FMEA } \\
\text { Tool: A Quality Improvement Report, Marcelo Espinheira et al }\end{array}$ \\
\hline Brazil & $\begin{array}{l}\text { Medical devices proactive surveillance - trends and impact from field and enforcement } \\
\text { actions in Brazil, MG Vincente }\end{array}$ \\
\hline Brazil & Structuring the Radiological Report, D.M. Rocha et al \\
\hline Brazil & $\begin{array}{l}\text { Development of an ubiquitous management platform in air compressors used in pri- } \\
\text { mary healthcare, I.L. Santos, F.S. Rosa, R. Garcia }\end{array}$ \\
\hline Brazil & $\begin{array}{l}\text { The Clinical Engineering in Hospital Accreditation Case Study: Radiology Clinic, R.A.M. } \\
\text { Sá et al }\end{array}$ \\
\hline Brazil & $\begin{array}{l}\text { Clinical Engineering/Health Technology regulation, evaluation \& training to improve } \\
\text { care delivery, Murilo Conto, Zeev Katz, (part2) }\end{array}$ \\
\hline China & $\begin{array}{l}\text { A Hospital-based Dynamic Warning System Medical Consumables Regarding Adverse } \\
\text { Event Management, Sun-Lv-Feng }\end{array}$ \\
\hline China & $\begin{array}{l}\text { Case Study and Management Improvement of Medical Devices, Jing-ying Gao, Lei Wei, } \\
\text { Yin-chun Lu }\end{array}$ \\
\hline China & Survey and analysis of current state of ventilator alarms in ICU, Lin, Zheng Kun \\
\hline China & Shanghai Region Medical Equipment Quality and Safety, Li Bin \\
\hline China & $\begin{array}{l}\text { Design of a Web-based Medical Equipment Management System for CE, 2015, Liu } \\
\text { Shenglin, Zhang Qiang, Wu Hanxi, Zhang Xutian, Wang Guohong }\end{array}$ \\
\hline Colombia & MoH Health Technology Management Regulations, Andrea Garcia-Ibarra \\
\hline Dominican Republic & $\begin{array}{l}\text { Medical - Surgical Vacuum and Anesthetic Residue Extraction Policy in the Dominican } \\
\text { Republic, Diogenes Hernandez }\end{array}$ \\
\hline Germany & $\begin{array}{l}\text { Technological Surveillance and Integrity Monitoring of Infusion Systems, D. Grosse- } \\
\text { Wentrup, U. M. Hoelscher }\end{array}$ \\
\hline Global & A pneumonia prevention system, Peter Young; Maryanne Mariyaselam \\
\hline Global & Global Professional Credentialing Project, Yadin David, Mario Medvedec, Jim Wear \\
\hline Global & $\begin{array}{l}\text { Adoption of medical-technologies in infrastructure-poor environments, Gisela Abbam, } \\
\text { Vikram Damodaran, Sally Lee }\end{array}$ \\
\hline Global & $\begin{array}{l}\text { Hospital Integrated Networks Risk Management - Issues and Recommendations, Yadin } \\
\text { David, (part2) }\end{array}$ \\
\hline
\end{tabular}




\begin{tabular}{|c|c|}
\hline Focus Area & Title, authors, with active links \\
\hline Global & Skill development for growth in emerging markets, Gisela Abbam, Marut Setia \\
\hline Global & Clinical Engineering Risk Management, Frank Painter \\
\hline Global & CE Certification globally to improve care delivery, Jim Wear, Mario Medvedec \\
\hline Global & Human Factors Engineering book - global resource, Tony Easty et al \\
\hline Global & Global training partnerships, Shauna Mullally \\
\hline Global & Promoting the Image of Biomedical Engineers and Improving Safety, Michael Cheng \\
\hline Global & Managing the medical equipment lifecycle resource, THET, Anna Worm \\
\hline Global & Medical Equipment Maintenance book, 2013, Binseng Wang \\
\hline Global & Profile of Biomedical Engineering Education in Latin America, SJ Calil et al \\
\hline Global & Preventable Adverse Events: How to? Yadin David \\
\hline Global & Medical Device Risk Management from a Human Factors Perspective, Tony Easty \\
\hline Global & Medical Devices Vigilance and the European Union Regulations, Nicolas Pallikarakis \\
\hline Italy & A new digital era of Clinical and Biomedical process, Giulia and Stefano Marchesi \\
\hline Italy, Egypt & $\begin{array}{l}\text { A New Approach for Preventive Maintenance Prioritization of Medical Equipment, Ne- } \\
\text { ven Saleh et al }\end{array}$ \\
\hline Japan & The role of policymakers for health technologies, Dr. Masato Mugitani \\
\hline Jordan & $\begin{array}{l}\text { Implementation of Six Sigma on Case Study at the Directorate of BME in the Jordanian } \\
\text { MoH, 2012, Adnan Al-Bashir, Akram Al-Tawarah }\end{array}$ \\
\hline Kenya & $\begin{array}{l}\text { Roadmap to validation and verification of Intravenous Devices in Kenya, Bintiomar Tsala, } \\
\text { Abdulatif Ali, Abel Onyango }\end{array}$ \\
\hline Kuwait & $\begin{array}{l}\text { Safe care: An initiative for regulations in Kuwait, WHO 2GFMD, 2013, Ms. Hanan Al-awa- } \\
\text { dhi, Association for Biomedical Engineers }\end{array}$ \\
\hline Mexico & Impact of State CE Directorate, Ignacio Macias, 2016 \\
\hline Mozambique, Portugal & Training program in Central Hospital of Maputo (2011-2016), Mario Forjaz Secca \\
\hline Papua New Guinea & $\begin{array}{l}\text { Improving pediatric and neonatal care in rural district hospitals in the highlands of } \\
\text { Papua New Guinea: a Quality Improvement approach, M. Saavu, Trevor Duke, Sens Matai }\end{array}$ \\
\hline Samoa, Fiji & User Care of Medical Equipment, Nehal Kapadia, Sunema Talapusi \\
\hline
\end{tabular}




\begin{tabular}{l|l}
\hline \multicolumn{1}{c|}{ Focus Area } & \multicolumn{1}{c|}{ Title, authors, with active links } \\
\hline Saudi Arabia & Unifying Efforts against Counterfeiting Medical Devices, Nazeeh Alothmany \\
\hline Taiwan & Actions of medical device post-market surveillance, KP Lin, Y-T Hung, Shiu- Huei Yeh \\
\hline USA & $\begin{array}{l}\text { Application of Quality, Risk \& Asset Management Principles to Clinical Engineering, Bin- } \\
\text { seng Wang, (part2) }\end{array}$ \\
\hline $\begin{array}{l}\text { Cape Verde, Senegal, The } \\
\text { Gambia, Guinea Bissau, } \\
\text { Guinea, Sierra Leone, Li- } \\
\text { beria, Mali, Ivory Coast, } \\
\begin{array}{l}\text { Ghana, Togo, Benin, Bur- } \\
\text { kina Faso, Nigeria, Niger }\end{array}\end{array}$ & $\begin{array}{l}\text { The West African Health Organization, Biomedical Engineering Curriculum, Bobo-Dioul- } \\
\text { asso et al, (part2) }\end{array}$ \\
\hline
\end{tabular}

